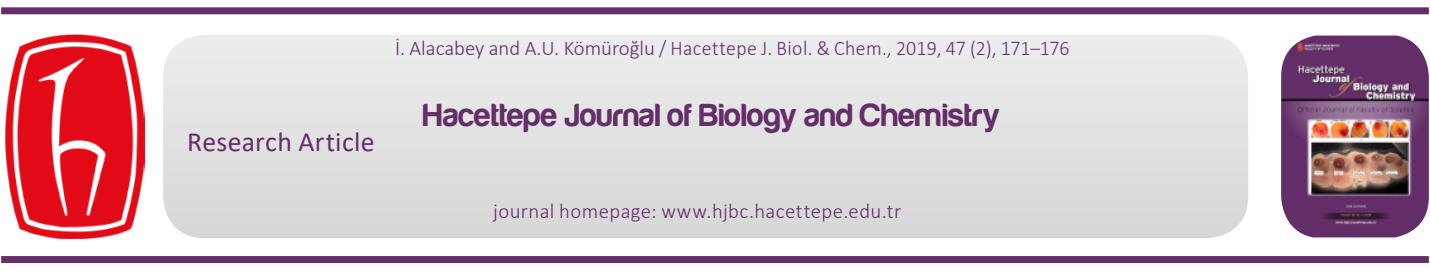

\title{
Determination of Hair and Serum Metal Levels in Petrol Station Workers
}

\section{Petrol İstasyon Çalışanlarında Saç ve Serum Metal Düzeylerinin Belirlenmesi}

\author{
Ahmet Ufuk Kömüroğlư ${ }^{\oplus}$, İhsan Alacabey ${ }^{\circledR} *$, Nurhayat Atasoy ${ }^{\circledR}$, Rıfkı Üçler $^{\circledR}$ \\ ${ }^{1}$ Van Vocational Higher School of Healthcare Studies, Van Yüzüncü Yıl University, Turkey. \\ ${ }^{2}$ Vocational Higher School of Healthcare Studies, Mardin Artuklu University, Turkey. \\ ${ }^{3}$ Department of Chemistry, Faculty of Science,Van Yüzüncü Yıl University, Turkey. \\ ${ }^{4}$ Department of Endocrinology and Metabolism, Medical Faculty, Yüzüncü Yıl University, Turkey.
}

\section{ABSTRACT}

The aim of this study is to determine some metals in hair and serum samples of petrol station workers. A total of 50 petro station workers (exposure group) and 50 office workers (control group) were included in the study. Li, Ni, V, TI, Ti and Sr levels in hair samples and $\mathrm{Sr}$, Ti and $\mathrm{V}$ levels in serum samples were measured using the ICP-OES instrument. Li, Ni, $\mathrm{V}$, TI, Ti and Sr levels in hair samples were found to be significantly higher in the exposure group than in the control group. Ti level in serum samples was found to be significantly higher in the exposure group than in the control group. However, Sr and $\mathrm{V}$ levels in serum samples did not differ significantly between the two groups. These results show that petrol station workers are exposed to these toxic metals. For this reason, it may be recommended that petrol station workers should undergo regular biomonitoring and healthcare screening.

\section{Key Words}

Hair, petrol station workers, ICP-OES, gasoline.

ÖZ

B u çalışmanın amacı petrol istasyonunda çalışan işçilerin saç ve seumlarında bazı metalleri belirlemektir. Toplam 50 petrol istasyonu işçisi (maruziyet grubu) ve 50 ofis çalışanı (kontrol grubu) çalışmaya dahil edildi. Saç örneklerinde Li, Ni, V, TI, Ti ve Sr serum örneklerinde Sr, Ti ve V ICP-OES kullanılarak ölçüldü. Saç örneklerinde Li, Ni, V, TI, Ti ve Sr maruziyet grubunda kontrolden anlamlı olarak yüksek bulunmuştur. Serum Ti seviyesi maruziyet grubunda kontrolden anlamlı olarak yüksek bulunmuştur. Sr ve $\mathrm{V}$ serum seviyeleri iki grup arasında anlamlı fark bulunmamıştır. Bu sonuçlar petrol istasyonu işçilerinin bu toksik metallere maruziyetini göstermektedir. Bu nedenle, petrol istasyonu işçilerinin düzenli biyogözlemlerinin ve sağlık taramalarının yapılması önerilir.

\section{Anahtar Kelimeler}

Saç, petrol isyasyonu işçileri, ICP-OES, petrol.

Article History: Received: Jan 30, 2019; Revised: Feb 25, 2019; Accepted: Mar 1, 2019; Available Online: Sep 15, 2019

DOI: $10.15671 /$ hjbc.622634

Correspondence to: I. Alacabey, Vocational Higher School of Healthcare Studies, Mardin Artuklu University, Turkey.

E-Mail: ihsanalacabey@hotmail.com 


\section{INTRODUCTION}

uman biomonitoring means the scientific method that is based on the sampling and analysis of human tissues and biological fluids and that assesses human exposure to environmental xenobiotics. Human biomonitoring has been reported to provide more accurate data than predictions based on measurements of concentrations of chemical compounds in the environment (such as soil, water, air, and food) [1]. Human biomonitoring allows to identify and screen the compounds that the human body receives from the environment. Population groups at risk of high exposure (infant, child, adult, elderly) may be an important source of exposure to persistent organic pollutants [1].

It is also a useful tool to monitor exposure trends across the entire population at specific time intervals. In addition, the results of biomonitoring are used to provide reference intervals of certain chemicals and then is used in environmental and health policies to reduce the risk of exposure to harmful substances [2].

Human hair is used in clinical and forensic sciences to provide evidence in important investigations [3]. However, the idea of using human hair as an indicator in assessing exposure to persistent organic pollutants has emerged in recent years. To date, it has been used as a bioindicator for adults exposed to selected persistent organochlorine pollutants and for children exposed to pesticides in different European countries [4]. Human hair offers several advantages in human biomonitoring thanks to its stability [1]. Two different ways for human hair exposure to environmental pollutants have been described in the literature: (1) internal (systemic) exposure through the blood, incorporation of chemicals into living cells in the hair bulb and (2) external exposure through the ingestion of atmospheric air and dust [5].

Petrol (gasoline) is a mixture of low molecular weight compounds, consists predominantly of hydrocarbon compounds such as olefins, naphthenes, paraffins, aromatic hydrocarbons (C11-C14 range) and has a boiling point of $30-260^{\circ} \mathrm{C}[6]$.

It is a complex combination of petroleum (also known as crude oil or simply oil) hydrocarbons. About $95 \%$ of the components in the vapor phase of gasoline are various aliphatic and alicyclic compounds, and usually less than $2 \%$ are aromatics [7]. Petrol station workers are exposed to oil vapors and vehicle exhaust fumes. The combined effect of these two pathways may result in accelerated decline of lung function [8].

Petrol stations are likely to have significant sources of carbonyl compounds and volatile organic compounds, especially benzene, toluene, ethylbenzene, and xylene (BTEX). For this reason, petrol station workers may be exposed to high concentrations of these compounds by inhalation without appropriate health protection. Respiratory exposure to these compounds can cause serious health problems depending on the concentration, type, and exposure duration of the chemical substance. Many studies have reported that petrol station workers are affected by exposure to these compounds [9-15].

Petrol station workers are chronically exposed to petroleum derivatives by inhalation of volatile petroleum fractions during oil filling [16]. In addition, they are exposed to vehicle exhaust fumes because oil filling stations are localized where traffic is high [17].

This study was conducted to determine the amount of trace elements in hair and serum samples of petrol station workers.

\section{MATERIALS and METHODS}

\section{Study Area}

This study was carried out in gas stations of 5 different oil companies in Van province of Turkey in June 2016. The study group consisted of 50 men who filled gasoline at various gas stations. The control group consisted of 50 healthy individuals of the similar age who were not exposed to oil vapors. The individuals in the study and control groups did not have any chronic disease and did not receive any medication for the last six months.

\section{Washing Method of Hair Samples}

Hair samples were washed three times with a non-ionic detergent (Tritonx100) and rinsed with diatomic water. The washing procedure was repeated three times. Then, hair samples were oven dried at $60^{\circ} \mathrm{C}$.

\section{Degradation Process}

$0.2000 \pm 0.0002 \mathrm{~g}$ was weighed from each of the washed and dried hair samples. $1 \mathrm{~mL}$ of concentrated analytically pure $\mathrm{HNO}_{3}$ was added on it. It was expected to penetrate for 8 hours. Then, $10 \mathrm{ml}$ of ultrapure water was added to the mixture. It was stored until $-20^{\circ} \mathrm{C}$ until analysis [18]. 


\section{Collection of Blood Samples}

Venous blood samples were collected early in the morning following 9-12-hour fasting from all participants. The samples were centrifuged for $10 \mathrm{~min}$ at $4.000 \mathrm{rpm} /$ $\mathrm{min}$, and serums were separated. Serum samples were kept at $-80^{\circ} \mathrm{C}$ until measurement day. Hair and serum metal levels were measured using the ICP-OES instrument (ICP-OES, Thermo ICAP 6300 DUO Scientific) at Van Yuzuncu YII University Science Application and Research Center.

\section{Statistical Method}

Statistical methods employed in the present study were Mean and Standard Deviation, Independent sample $t$-test using SPSS-23. The $p$ value less than 0.05 was considered statistically significant.The manuscript should be written as clearly and concisely as possible. Materials and Methods should be explained via bold titles.

\section{RESULTS and DISCUSSION}

Ti level in serum samples was found to be significantly higher in the exposure group than in the control group. However, Sr and $\mathrm{V}$ levels in serum samples did not differ significantly between the two groups.

$\mathrm{Li}, \mathrm{Ni}, \mathrm{V}, \mathrm{TI}, \mathrm{Ti}$ and $\mathrm{Sr}$ levels in hair samples were found to be significantly higher in the exposure group than in the control group.

Determination of trace metals in human tissues and fluids is used to obtain information about nutritional status, diagnosis of diseases, symptoms of systemic toxicity, and environmental exposure [19-21].

Petroleum products are the main source of hazardous chemicals containing benzene in gas stations. Petrol station workers are at risk of exposure to benzene. Petroleum stream contributes to the increased level of exposure to these chemicals. Crude oil is mainly composed of hydrocarbons but contains oxygen, sulfur, nitrogen, and metals $[22,23]$. Metals and metalloids can be found naturally in crude oil or can be added during production, transportation, and storage $[23,24]$. Some metals can be responsible for environmental contamination and are carcinogenic compounds [25, 26].

Vanadium is a transition metal. It is present in the earth's crust at concentrations of around $0.014 \mathrm{~g} / \mathrm{kg}$. It is the fifth most abundant trace element among the transition metals and is the 20th most abundant element. It is found naturally in minerals and can be combined with coal and oil. Vanadium is the most abundant trace element in petroleum products. Vanadium concentrations in petroleum may be as high as $1,500 \mathrm{mg} /$ $\mathrm{kg}$, while some crude oils contain $<0.1 \mathrm{mg} / \mathrm{kg}$ [27]. In particular, vanadium has been shown to be one of the most common elements in crude oil [28]. It has been reported that vanadium levels are high in hair samples of people working in crude oil refineries and crude oil production processes [29]. Studies have shown that hair vanadium level is $0.016 \mathrm{ng} / \mathrm{mg}$. The present study found that hair vanadium level was significantly higher in the exposure group than in the control group $(p=0.016)$. There was no significant difference in serum vanadium level between the two groups.

$\mathrm{Sr}$ is an osteotrophic or bone-seeking trace element found normally in the diet and body tissues. Although strontium metabolism closely resembles the metabolism of calcium, it is still not considered to be an essential trace element [30]. Similar to other members of group 2 in periodic table such as calcium and magnesium, strontium forms a divalent cation in biological fluid. It binds to proteins in different degrees in biological fluids such as serum or plasma. The degree of binding of $\mathrm{Sr}$ to serum and plasma proteins is similar to that of calcium [31]. Studies on healthy volunteers have reported that hear Sr level is $867 \mathrm{ng} / \mathrm{g}$ [31 and $0.89 \mathrm{ng} / \mathrm{mg}$ [32], respectively. The present study found that hair Sr level was significantly higher in the exposure group than in the control group $(p<0.015)$.

Nickel (Ni) is a metallic element naturally found in plants, animals, and soils [33]. Ni and its compounds enter the atmosphere through natural resources (volcanic

Table 1. Serum metal levels of exposure and control groups.

\begin{tabular}{llll}
\cline { 2 - 3 } & Exposure & Control & $P$ \\
\cline { 2 - 4 } $\operatorname{Sr}(\mathrm{ppm})$ & $0.0102 \pm 0.0013$ & $0.110 \pm 0.0004$ & 0.078 \\
\hline $\mathrm{Ti}(\mathrm{ppm})$ & $0.0007 \pm 0.0003$ & $0.0004 \pm 0.0001$ & 0.028 \\
\hline $\mathrm{V}(\mathrm{ppm})$ & $0.0515 \pm 0.008$ & $0.0533 \pm 0.002$ & 0.150 \\
\hline
\end{tabular}


Table 2. Hair metal levels of exposure and control groups.

\begin{tabular}{llll}
\hline & Exposure & Control & $P$ \\
\hline $\mathrm{Li}(\mathrm{ppm})$ & $0.0243 \pm 0.014$ & $0.0026 \pm 0.0017$ & 0.008 \\
\hline $\mathrm{Ni}(\mathrm{ppm})$ & $0.0107 \pm 0.009$ & $0.006 \pm 0.002$ & 0.041 \\
\hline $\mathrm{Sr}(\mathrm{ppm})$ & $0.142 \pm 0.025$ & $0.068 \pm 0.011$ & 0.011 \\
\hline $\mathrm{Ti}(\mathrm{ppm})$ & $0.054 \pm 0.010$ & $0.014 \pm 0.001$ & 0.000 \\
\hline $\mathrm{Tl}(\mathrm{ppm})$ & $5.717 \pm 1.517$ & $0.716 \pm 0.107$ & 0.000 \\
\hline $\mathrm{V}(\mathrm{ppm})$ & $0.553 \pm 0.107$ & $0.260 \pm 0.049$ & 0.016 \\
\hline
\end{tabular}

eruption, wind, vegetation, forest fire) as well as human activities (mining, smelting, refining, alloy production, fossil fuel burning, waste incineration) [34]. Ni and its compounds show toxic effects. Its toxic effect depends on its chemical species and physical structure as well as its concentration and exposure pathway. The most common harmful effect of $\mathrm{Sr}$ in the general population is allergic contact dermatitis due to prolonged skin contact. When compared with the general population, occupationally exposed people have a higher risk of respiratory tract cancer due to inhalation of nickel at their workplace in the nickel-producing or using industries [35]. The International Agency for Research on Cancer (IARC) classified nickel compounds as being carcinogenic to humans (Group 1) [33]. Blood, tissues, urine, and feces are used as biomaterials of $\mathrm{Ni}$ exposure. $\mathrm{Ni}$ can be measured in other tissues such as nails and hair. In one study conducted with adult healthy populations in three different Pakistani cities, the concentration of $\mathrm{Ni}$ in hair was found to be $9 \mu \mathrm{g} / \mathrm{g}$ in adult males and 6.5 $\mu \mathrm{g} / \mathrm{g}$ in adult females [36]. In other study performed in adults without occupational exposure in Moscow, the concentration of $\mathrm{Ni}$ in hair was determined to be 0.413 $\mu \mathrm{g} / \mathrm{g}$ [37]. Another study conducted in children in Spain reported that the concentration of $\mathrm{Ni}$ in hair was 0.58 $\mu \mathrm{g} / \mathrm{g}$ [38]. The present study found that hair Ni level was significantly higher in the exposure group than in the control group $(p=0.001)$.

Titanium (Ti) is a non-essential element for humans. $\mathrm{Ti}$ can be measured in blood, brain, parenchymatous organs, and hair [39, 40]. Approximately $95 \%$ of titanium is consumed in the form of titanium dioxide (TiO2). Its microparticles and nanoparticles are widely used in consumer products containing cosmetics and foods suitable for the general population $[41,42]$. It is believed that $\mathrm{Ti}$ does not play an important role in the human body and is non-toxic even at high doses. However, the widespread use of $\mathrm{TiO} 2$ nanoparticles and their release to the environment have suggested significant health concerns about the potential health risks of $\mathrm{Ti}$ [43]. In one study performed in healthy controls in Southern China, it was revealed that the concentration of $\mathrm{Ti}$ in hair was $0.71 \pm 0.65 \mathrm{mg} / \mathrm{gr}$ [44]. The present study found that hair and serum Ti levels was significantly higher in the exposure group than in the control group.

Thallium is one of the most toxic metals and can cause acute and chronic poisoning $[45,46]$. Thallium is chemically similar to potassium. $\mathrm{Tl}+$ displaces $\mathrm{K}+$ in the activation of $\mathrm{Na}+/ \mathrm{K}+-$ ATPase in plasma cell membranes. This displacement may allow $\mathrm{Tl}+$ to pass on the cell membrane, to accumulate in the cells and to attack the mitochondrial respiratory chain [47]. This process is thought to play an important role in Tl-induced neuropathy [48]. The concentration of $\mathrm{Tl}$ in hair has been reported to be 0.018 ppm [48]. In healthy people without TI exposure, the concentration of $\mathrm{Tl}$ in hair has been reported to be $0.02 \mu \mathrm{g} / \mathrm{g}$ [49]. The present study found that hair TI level was significantly higher in the exposure group than in the control group.

The fact that the present study found that $\mathrm{Li}, \mathrm{Ni}, \mathrm{V}, \mathrm{TI}, \mathrm{Ti}$ and $\mathrm{Sr}$ levels in hair samples were significantly higher in the exposure group than in the control group demonstrates that petrol station workers are at high risk for important health problems. In particular, when compared with the control group, hair $\mathrm{Tl}$ and $\mathrm{Ni}$ levels were found to be about 8 and 17 times higher in the exposure group, respectively.

\section{Conflict of Interest}

The authors declare no conflict of interest. 


\section{References}

1. S. Król, b. Zabiegała, j. Namieśnik, Human hair as a biomarker of human exposure to persistent organic pollutants (POPs) TracTrends in Analyt. Chem, 47 (2013) 84-98.

2. J. Angerer, U. Ewers, M. Wilhelm, Human biomonitoring: state of the art, Int. J. Hyg. Environ. Health., 210 (2007) 20128.

3. A. Ilyas, M.H. Shah, Disparities of Selected Metal Levels in the Blood and Scalp Hair of Ischemia Heart Disease Patients and Healthy Subjects, Biol. Trace. Elem. Res., 180 (2007) 191-205.

4. A. Covaci, M. Tutudaki, A.M. Tsatsakis, P. Schepens, Hair analysis: another approach for the assessment of human exposure to selected persistent organochlorine pollutants, Chemosphere, 46 (2002) 413-418.

5. B.M.R. Appenzeller, A.M. Tsatsakis, Hair analysis for biomonitoring of environmental and occupational exposure to organic pollutants: state of the art, critical review and future needs, Toxicol. Lett., 210 (2012) 119-140.

6. R. Beerappa, D. Venugopal, S. Sen, M. Ambikapathy, R. Rao, Assessment of 8-oxo-7,8-dihydro-2'-deoxyguanosine as a marker of oxidative DNA damage in gasoline filling station attendants, Int. J. Occup. Med. Environ. Health., 26 (2013) 780 789.

7. S. Gupta, T.D. Dogra, Air pollution and human health hazards, Indian. J. Occup. Environ. Med., 6.2 (2002) 89-93.

8. S. Begum, M.B. Rathna, Pulmonary function tests in petrol filling workers in Mysore city, Pak. J. Physiol., 8.1 (2012) 1214.

9. U. Özdek, i. Alacabey, N. Akman Alacabey, A.U. Kömüroğlu, A.R. Kul, N. Atasoy, U. Mercan Yücel, S. Kaptanoğlu, R. Üçler, Petrol İstasyonu Çalışanlarında Manganez (Mn) Düzeyinin Belirlenmesi, Yüzüncü Yıl Üniversitesi Fen Bilimleri Enstitüsü Dergisi, 22 (2017) 97-101.

10. A.U. Kömüroğlu, I. Alacabey, N. Akman Alacabey, U. Özdek, A.R. Kul, N. Atasoy, U. Mercan Yücel, Selenium Concentration in Serum and Hair of Petrol Station Workers in Van Province /Turkey, IOSR J.Appl. Chem., (IOSR-JAC), 10.11.Ver II (2017) 47-50

11. İ. Alacabey, A.U. Kömüroğlu, N. Akman Alacabey, U. Özdek, A.R. Kul, N. Atasoy, U. Mercan Yücel, Determination of Cobalt (Co) level in hair and serum of Gas Station Workers in Van Province, IOSR J. Environ. Sci., Toxicol. Food Technol. (IOSR-JESTFT), 11 (2017) 30-32.

12. M. Kitwattanavong, T. Prueksasit, D. Morknoy, T. Tunsaringkarn, W. Siriwong, Health Risk Assessment of Petrol Station Workers in the Inner City of Bangkok, Thailand, to the Exposure to BTEX and Carbonyl Compounds by Inhalation, Hum. and Ecol. Risk. Assess. Internat. J., 19 (2013) 1424-1439.

13. J.F. Periago, A. Zambudio, C. Prado, Evaluation of environmental levels of aromatic hydrocarbons in gasoline service stations by gas chromatography, J. Chromatogr. A. 778 (1997) 263-268.

14. W.K. Jo, K.B. Song, Exposure to volatile organic compounds for individuals with occupations associated with potential exposure to motor vehicle exhaust and/or gasoline vapor emissions, Sci. Total. Environ., 269 (2001) 25-37.

15. P. Thaveevongs, S. Panyamateekul, T. Prueksasit, Exposure risk assessment of volatile organic compounds (VOCs) of the workers at gas station in Bangkok, Engineer. J., 2 (2010) 1-12.
16. A. Çelik, T. Çavaş, S. Ergene-Gözükara, Cytogenetic biomonitoring in petrol station attendants: micronucleus test in exfoliated buccal cells, Mutagenesis, 18 (2003) 417 421.

17. Y. Wei, I.K. Han, M. Shao, M. Hu, J. Zhang, X. Tang, PM2.5 constituents and oxidative DNA damage in humans, Environ. Sci. Technol., 43 (2009) 4757-4762.

18. J.A. Menezes-Filho, C.R. Paes, Â.M.D.C. Pontes, J.C. Moreira, P.N. Sarcinelli, D. Mergler, High levels of hair manganese in children living in the vicinity of a ferro-manganese alloy production plant. Neurotoxicology, 30 (2009) 1207-1213.

19. R.F.M. Herber, M. Stoeppler, Trace element analysis in biological specimens, Elsevier, Volume 15, 1st Edition, Amsterdam, 1994.

20. S.A. Katz, A. Chatt, Hair analysis: applications in the biomedical and environmental sciences, VCH Publishers, New York, 1989.

21. D.R. Baldwin, W.J. Marshall, Heavy metal poisoning and its laboratory investigation, Ann. Clin. Biochem., 36 (1999) 267 300.

22. J.H. Gary, G.E. Handwerk, M.J. Kaiser, Petroleum refining technology and economics. Fifth Edition, CRC press, New York, 2007.

23. J. Speight, Handbook of petroleum analysis, John Wiley \& Sons. Inc., New York, 2001.

24. S. Matar, L.F. Hatch, Chemistry of petrochemical processes. Gulf Professional Publishing, 2nd Edition, 2001.

25. R.M. DE Souza, A.L. Meliande, C.L. Da Silveira, R.Q. Aucélio, Determination of $\mathrm{Mo}, \mathrm{Zn}, \mathrm{Cd}, \mathrm{Ti}, \mathrm{Ni}, \mathrm{V}, \mathrm{Fe}, \mathrm{Mn}, \mathrm{Cr}$ and $\mathrm{Co}$ in crude oil using inductively coupled plasma optical emission spectrometry and sample introduction as detergentless microemulsions, Microchem. J., 82 (2006) 137-141.

26. B. Škrbić, J. Novaković, N. Miljević, Mobility of heavy metals originating from bombing of industrial sites, J. Environ. Sci. and Health., Part A., 37 (2002) 7-16.

27. F.A. Amorim, B. Welz, A.C. Costa, F.G. Lepri, M.G. Vale, S.L. Ferreira, Determination of vanadium in petroleum and petroleum products using atomic spectrometric techniques, Talanta, 72 (2007) 349-359.

28. C. Hardaway, J. Sneddon, J.N. Beck, Determination of metals in crude oil by atomic spectroscopy, Analyt. Lett., 37 (2004) 2881-2899.

29. A.V. Skalny, G.A. Kaminskaya, T.I. Krekesheva, S.K. Abikenova, M.G. Skalnaya, E.S. Berezkina, A.R. Grabeklis, A.A. Tinkov, The level of toxic and essential trace elements in hair of petrochemical workers involved in different technological processes, Environ. Sci. Pollut. Res., 24 (2017) 5576-5584.

30. H.A. Schroeder, I.H. Tipton, A.P. Nason, Trace metals in man: strontium and barium J. Chronic. Dis., 25 (1972) 491-517.

31. S. Pors Nielsen, The biological role of strontium, Bone, 35.3 (2004) 583-588.

32. J.P. Goullé, L. Mahieu, J. Castermant, N. Neveu, L. Bonneau, G. Lainé, D. Bouige, C. Lacroix, Metal and metalloid multielementary ICP-MS validation in whole blood, plasma, urine and hair: Reference values, Forensic. Sci. Int., 153 (2005),3944.

33. IARC. A Review of Human Carcinogens. C. Metals, Arsenic, Fibres and Dusts: Lyon: IARC, 2012.

34. ATSDR. Toxicological Profile for Zinc. Agency for Toxic Substances and Disease Registry, US Public Health Service, 2005. 
35. D. Schaumlöffel, Nickel species: analysis and toxic effects, J. Trace. Elem. Med. Biol., 26 (2012) 1-6.

36. F. Batool, S. Iqbal, K.W. Chan, M.I. Tariq, A. Shah, M Mustaqeem, Concentrations of heavy metals in hair and nails of young Pakistanis: correlation with dietary elements, Environ. Foren., 16 (2015) 1-6.

37. A.V. Skalny, M.G. Skalnaya, A.A. Tinkov, E.P. Serebryansky, V.A. Demidov, Y.N. Lobanova, A.R. Grabeklis, E.S. Berezkina, I.V. Gryazeva, A.A. Skalny, A.A. Nikonorov, Reference values of hair toxic trace elements content in occupationally nonexposed Russian population Environ. Toxicol. Pharmacol., 40 (2015) 18-21.

38. A. Pena-Fernandez, M. Gonzalez-Munoz, M. Lobo-Bedmar, "Reference values" of trace elements in the hair of a sample group of Spanish children (aged 6-9 years) - Are urban topsoils a source of contamination?, Environ. Toxicol. Pharmacol., 38 (2014) 141-152.

39. S.W. Fage, J. Muris, S.S. Jakobsen, J.P. Thyssen, Titanium: a review on exposure, release, penetration, allergy, epidemiology, and clinical reactivity, Contact Dermatitis, 74 (2016) 323-345.

40. D.C. Paschal, E.S. Dipietro, D.L. Phillips, E.W. Gunter, Age dependence of metals in hair in a selected US population,Environ. Res., 48 (1989) 17-28.

41. 41. V. Vijayaraghavan, A.V. Sabane, K. Tejas, Hypersensitivity to titanium: a less explored area of research, J. Indian. Prosthodontic. Soc., 12 (2012) 201-207.
42. A. Weir, P. Westerhoff, L. Fabricius, K. Hristovski, N. Von Goetz, Titanium dioxide nanoparticles in food and personal care products, Environ. Sci. Technol., 46 (2012) 2242-2250.

43. Z. Li, W. Huo, Z. Li, B. Wang, J. Zhang, A. Ren, Association between titanium and silver concentrations in maternal hair and risk of neural tube defects in offspring: A case-control study in north China, Reprod. Toxicol., 66 (2016) 115-121.

44. P.L. Leung, H.M. Huang, Analysis of trace elements in the hair of volunteers suffering from naso-pharyngeal cancer.,Biol. Trace. Elem. Res., 57 (1997) 19-25.

45. V. Zitko, Toxicity and pollution potential of thallium, Sci. Total. Environ., 4 (1975) 185-192.

46. I.C. Smith, B.L. Carson, Trace metals in the environment. Thallium, vol. 1. Ann Arbor, Michigan Ann Arbor Science Publishers, 1977.

47. P.S. Spencer, E.R. Peterson, R. Madrid, C.S. Raine, Effects of thallium salts on neuronal mitochondria in organotypic cord-ganglia-muscle combination cultures, J. Cell. Biol., 58 (1973) 79-95.

48. A. Léonard, G.B. Gerber, Mutagenicity, carcinogenicity and teratogenicity of thallium compounds, Mutation Research/ Reviews in Mutation Research, 387 (1997) 47-53.

49. J.J. Rodriguez-Mercado, M.A. Altamirano-Lozano, Genetic toxicology of thallium: a review, Drug. Chem. Toxicol., 36 (2013) 369-83. 